\title{
Ex Vivo Expansion of Human Umbilical Cord Blood- Derived T-Lymphocytes with Homologous Cord Blood Plasma
}

\author{
Yong-Man Kim, Min-Hyung Jung, Ha-Young Song, Hyun Ok Yang, ${ }^{1}$ Sung-Tae \\ Lee, ${ }^{2}$ Jong-Hyeor Kim, Young-TaK Kim, Joo-Hyun Nam and Jung-Eun MoK \\ Department of Obstetrics and Gynecology, College of Medicine, University of \\ Ulsan, Asan Medical Center, Seoul, \\ ${ }^{1}$ Korea Institute of Science and Technology, Seoul, and \\ ${ }^{2}$ Department of Internal Medicine, College of Medicine, Yonsei University, \\ Seoul, Korea
}

Kim, Y.M., Jung, M.H., Song, H.Y., Yang, H.O., LeE, S.T., Kim, J.H., Kim, Y.T., Nam, J.H. and Moк, J.E. Ex Vivo Expansion of Human Umbilical Cord Blood-Derived T-Lymphocytes with Homologous Cord Blood Plasma. Tohoku J. Exp. Med., 2005, 205 (2), 115-122 — This study was designed to establish a more effective and safe culture system for adoptive immunotherapy by investigating the use of homologous cord blood plasma (HCBP) instead of fetal bovine serum (FBS), which has various limitations including ethical problems for the ex vivo expansion of human umbilical $\mathrm{T}$ lymphocytes. Fresh human umbilical mononuclear cell fractions were isolated by Ficoll-Hypaque density centrifugation. Nonadherent mononuclear cell fractions were cultured with anti-CD3 antibody ( $5 \mu$ $\mathrm{g} / \mathrm{ml})$, IL-2 (175 U/ml), and either 10\% FBS or 10\% HCBP. On day 8, the cellular proliferation rate and cell surface markers were assessed. There was no significant difference in proliferation when human umbilical cord blood $\mathrm{T}$ lymphocytes were grown in medium supplemented with FBS or HCBP $(p>0.05)$. In medium containing FBS, the proportion of $\mathrm{CD}^{+} \mathrm{CD}^{+}$(markers for helper T cell), $\mathrm{CD}^{+} \mathrm{CD}^{+}$(cytotoxic $\mathrm{T}$ cell), $\mathrm{CD}^{+} \mathrm{CD}^{2} 5^{+}$(activated $\mathrm{T}$ cell), $\mathrm{CD}^{+} \mathrm{CD} 38^{+}$(immature $\mathrm{T}$ cell), and $\mathrm{CD} 3^{+} \mathrm{CD} 45 \mathrm{RO}^{+}$(memory $\mathrm{T}$ cell) cells was significantly increased $(p<0.05)$, whereas proportion of $\mathrm{CD}^{+} \mathrm{CD}^{+} 5 \mathrm{RA}^{+}$(naive $\mathrm{T}$ cell) and $\mathrm{CD} 16^{+} \mathrm{CD} 56^{+}$(NK cell) cells was significantly decreased $(p<0.05)$. In HCBP supplemented medium, the proportion of $\mathrm{CD}^{+} \mathrm{CD} 8^{+}, \mathrm{CD}^{+} \mathrm{CD} 25^{+}, \mathrm{CD}^{+} \mathrm{CD} 45 \mathrm{RA}^{+}$, and $\mathrm{CD}^{+} \mathrm{CD} 45 \mathrm{RO}^{+}$cells was significantly increased $(p<0.05)$. The proportion of $\mathrm{CD}^{+} \mathrm{CD}^{+}, \mathrm{CD}^{+} \mathrm{CD}^{+} 5 \mathrm{RO}^{+}$and $\mathrm{CD} 3^{+} \mathrm{CD} 38^{+}$cells was significantly higher, but proportion of $\mathrm{CD}^{+}{ }^{+} \mathrm{CD} 45 \mathrm{RA}^{+}$and $\mathrm{CD} 3^{+} \mathrm{CD} 8^{+}$cells was significantly lower in FBS compared with HCBP supplemented medium $(p<0.05)$. Our results support the feasibility of ex vivo expansion of human umbilical cord blood $\mathrm{T}$ lymphocytes in medium supplemented with HCBP for future adoptive cellular immunotherapy. —— human umbilical cord blood; T lymphocytes; ex vivo expansion; fetal bovine serum; homologous umbilical cord blood plasma

(C) 2005 Tohoku University Medical Press

Received October 20, 2004; revision accepted for publication November 30, 2004.

Address for reprints: Yong-Man Kim, Department of Obstetrics and Gynecology, University of Ulsan, Asan Medical Center, 388-1 Pungnap-2-dong, Songpa-gu, Seoul 138-736, Korea.

e-mail: ymkim@amc.seoul.kr 
Human umbilical cord blood (UCB) has been used as an alternative to allogeneic bone marrow and mobilized peripheral blood stem cell transplantation as a source of hematopoietic stem cells for the treatment of acquired and genetic diseases (D'Arena et al. 1996). Potential advantages of UCB include no risk to the donor, no donor attrition, minimal risk of viral transmission, immediate availability, higher proliferative potential, and lower incidence of acute graft-versus-host disease (GvHD), which may translate into less stringent HLA matching requirements (Gluckman et al. 1997; Lewis 2002).

Several limitations are associated with using unrelated UCB, including a delay in T cell reconstitution and, more importantly, the lack of available donor immunoeffector cells for adoptive cellular immunotherapy after transplantation (Barker et al. 2001). Compared with adult sources of $T$ lymphocytes, UCB T lymphocytes represent a more primitive and immature population, and consequently, may be more refractory to ex vivo expansion. Some studies have reported that UCB $\mathrm{T}$ cells have a reduced proliferative responsiveness to certain mitogenic plant lectins, alloantigens (Harris et al. 1992) and monoclonal antibodies (Bertotto et al. 1990) in the mixed leukocyte reaction (MLR), relative to adult peripheral blood $\mathrm{T}$ cells. Others have reported, however, that the proliferative response of UCB T cells to mitogens and alloantigens is normal, but that cytotoxic alloreactivity is not generated in UCB T cells in the MLR (Risdon et al. 1995). In addition, stimulation of UCB T cells results in a cytokine profile different from that of adult $\mathrm{T}$ cells (Harris et al. 1992). The relative immaturity and altered immunoreactivity of UCB T cells may account for the decreased incidence and severity of clinically observed GvHD in cord blood transplant recipients (Wagner et al. 1996). UCB T cells can be expanded to a level sufficient for engraftment of an average-sized adult (Conrad and Emerson 1998).

Immunotherapy with ex vivo expanded immune cells has become a promising tool for the treatment of a wide range of diseases, including cancers and viral infections. Such therapies have been used to restore host immunity and to prevent the development of iatrogenic infections in immunodeficient patients, such as those recovering from chemotherapy, systemic viral infections or organ transplants (Walter et al. 1995; Rooney et al. 1998). Alternatively, therapeutic cells can be designed to specifically target and eradicate malignant or virally infected cells (Mehta-Damani et al. 1994). The ex vivo expansion of T lymphocytes using a combination of anti-CD3 antibody and interleukin (IL)-2 has been also used in adoptive cancer-based cellular immunotherapy and vaccine trials (Chang et al. 1997; Curti et al. 1998).

We have used anti-CD3 antibody and IL-2 in the ex vivo generation of mature and activated $\mathrm{T}$ cells from human UCB as previously reported by Azuma et al. (2002). To achieve sufficient expansion, the culture medium is usually supplemented with fetal bovine serum (FBS) or autologous cord blood plasma (ACBP) (Skea et al. 1999; Carlens et al. 2000). For clinical applications, however, FBS is not permitted for ethical reasons as well as for its undefined nature and lot-to-lot variations. ACBP is difficult to obtain in sufficient quantities to use for all the steps required in ex vivo expansion and transplantation. One alternative to the use of FBS or ACBP is homologous cord blood plasma (HCBP) because of its relatively easy accessibility and safety. We have therefore investigated whether the alternative use of HCBP as a culture medium supplement instead of FBS will yield a predictable and efficient expansion of UCB T lymphocytes for future adoptive immunotherapy.

\section{Materials and Methods}

Collection and processing of human umbilical cord blood We collected 24 UCB samples at the time of delivery from uncomplicated normal full-term pregnancies, after obtaining informed consent, at Asan Medical Center, Seoul, Korea. The study protocol was approved by Institutional Review Board. Following aseptic preparation of the cord, the umbilical vein was punctured with a sterile 18-gauge needle attached to sterile tubing and to a $175 \mathrm{ml}$ sterile collection bag (Greencross, Korea) containing $23 \mathrm{ml}$ of citrate-phosphate-dextrose as an antico- 
agulant, and the UCB was collected by gravity flow with constant rocking. Case in which the placenta or cord was abnormal, where there was suspicion of infection or congenital malformation of the baby, or where the volume of blood obtained was under $60 \mathrm{ml}$, were excluded from the study. Twelve UCB samples were cultured in medium supplemented with FBS, whereas the other 12 were cultured in medium supplemented with HCBP.

\section{Assay of cell surface markers}

Aliquots of UCB cells were suspended in $100 \mu 1$ phosphate-buffered saline (PBS) containing 2\% FBS and $0.02 \%$ sodium azaide $\left(\mathrm{NaN}_{3}\right)$ and incubated with mouse IgG (Inter-Cell Technologies, Hopewell, NJ, USA) to block nonspecific binding. The cells were subsequently incubated for 30 minutes at $4{ }^{\circ} \mathrm{C}$ in the dark with fluorescein (FITC)- or phycoerythrin (PE)-conjugated monoclonal anti-CD3 (R\&D Systems, Minneapolis, MN, USA), anti-CD4, anti-CD8, anti-CD25, anti-CD16/56 (Serotec, Oxford, UK), anti-CD38, anti-CD45RA, or antiCD45RO (Becton-Dickinson, San Jose, CA, USA) antibodies. The cells were washed twice to remove unbound antibodies, resuspended in PBS containing $2 \%$ FBS and $0.02 \% \mathrm{NaN}_{3}$, passed through a nylon mesh filter and subjected to two-color flow cytometric analysis within 24 hours. Cells incubated with FITC-conjugated mouse IgG1 and PE-conjugated mouse IgG2a (DakoCytomation, Denmark, A/S) were used as negative controls. Flow cytometry was performed on a FACScan analyzer (BectonDickinson) equipped with a filter set for FITC-PE dualcolor fluorescence, coupled to CellQuest research software (Becton-Dickinson). At least 10,000 events were acquired for each analysis.

\section{Ex vivo expansion of T lymphocytes}

Lymphocytes were isolated by Ficoll-Hypaque density gradient centrifugation and expanded as described (Azuma et al. 2002). Briefly, T-25 flasks were treated with anti-CD3 antibody (5 ug/ml in PBS) for 2 hours and washed several times with PBS. To each flask was added $5 \times 10^{6}$ cord blood lymphocytes in $6.6 \mathrm{ml}$ RPMI 1640 (Gibco) supplemented with 10\% FBS or 10\% HCBP plus $175 \mathrm{U} / \mathrm{ml}$ recombinant human IL-2 (R\&D Systems), and the flasks were incubated for 4 days. The cells were transferred to non-coated flasks and incubated in the same medium for an additional 10 days, maintaining the cell concentration at 1 to $2 \times 10^{6} / \mathrm{ml}$. At each feeding, cell viability was evaluated by trypan blue exclusion (Gibco).

\section{Statistical analysis}

Differences between cell cultures were evaluated using the Mann-Whitney's U-test, student's paired $t$-test, or the Kruskal-Wallis test, as appropriate. $P$ values of $<$ 0.05 were considered statistically significant.

\section{Results}

\section{Ex vivo expansion of lymphocytes}

When we assayed lymphocyte amplification (Fig. 1), we observed no significant differences on days 11 and 12 in proliferation of umbilical cord blood T-lymphocytes incubated in media supplemented with FBS and HCBP $(p>0.05)$.

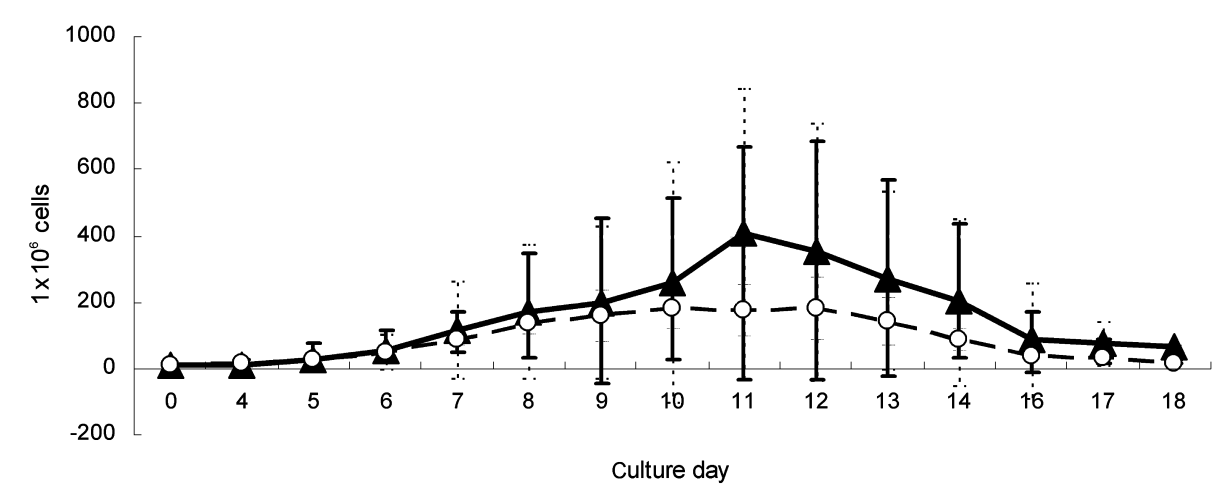

Fig. 1. Mean T-lymphocyte expansion rates in media supplemented with $10 \%$ FBS and $10 \%$ HCBP. No significant differences on days 11 and 12 in proliferation of UCB T-lymphocytes incubated in media supplemented with FBS and $\operatorname{HCBP}(p>0.05)$.

UCB, umbilical cord blood; FBS, fetal bovine serum; HCBP, homologous cord blood plasma.

$\longrightarrow$, FBS-mean \pm S.D.; $-\infty$, HCBP-mean \pm S.D. 
Assay of cell surface markers

When we assayed cell surface markers on the expanded cord blood lymphocytes on day 8 , we found that $\mathrm{CD}^{+}$was expressed on over $95 \%$ of cells cultured under both conditions, compared with precultured cells (Fig. 2). When cultured in medium supplemented with FBS, the expression of $\mathrm{CD}^{+} \mathrm{CD}^{+}$(helper T cell, $49.58 \% \pm 11.80 \%$ vs $78.68 \% \pm 11.64 \%$ ), $\mathrm{CD}^{+} \mathrm{CD}^{+}$(cytotoxic $\mathrm{T}$ cell, $19.78 \% \pm 7.66 \%$ vs $52.25 \% \pm 7.23 \%)$
Pre-Culture
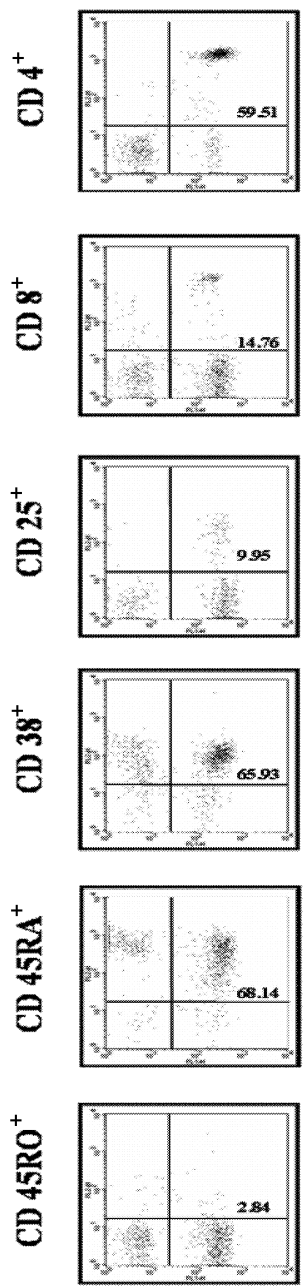

\section{Post-Culture}

FBS

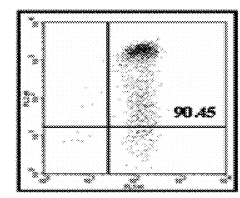

HCBP
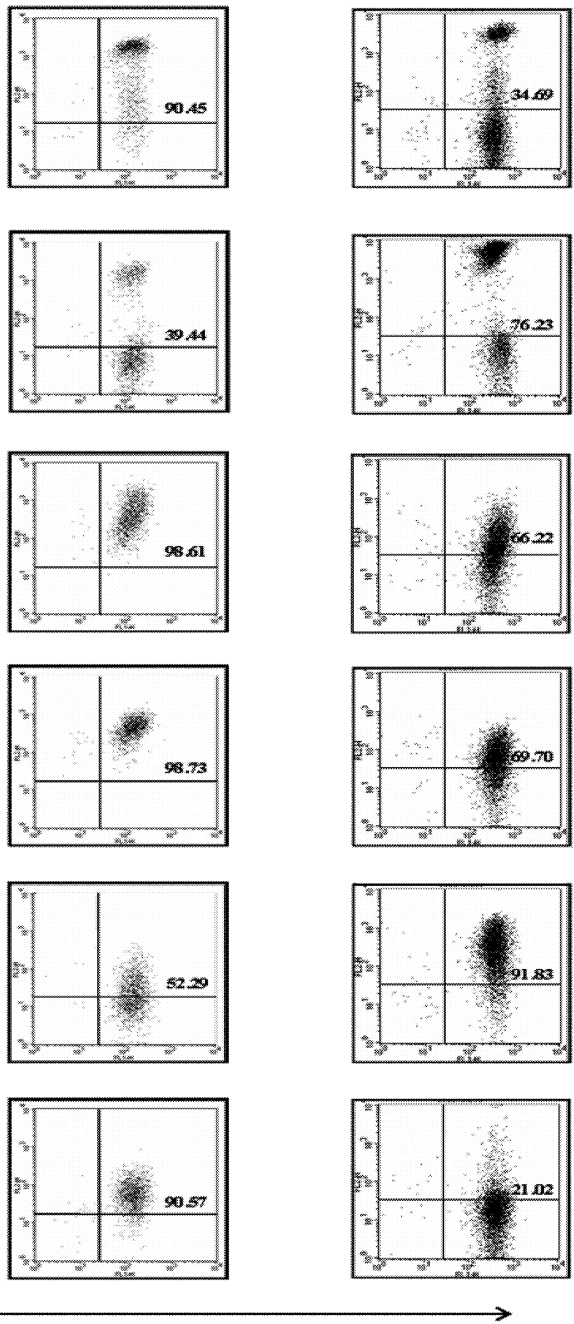

CD 3

Fig. 2. Analysis of cell surface phenotype on day 8 . The $\mathrm{CD}^{+}$was expressed on over $95 \%$ of cells cultured under both conditions, compared with precultured cells. The expression of $\mathrm{CD}^{+} \mathrm{CD}^{+}$, $\mathrm{CD}^{+} \mathrm{CD} 25^{+}$, and $\mathrm{CD}^{+} \mathrm{CD} 45 \mathrm{RO}^{+}$cell was quite increased in $\mathrm{HCBP}$ supplemented media.

FBS, fetal bovine serum; HCBP, homologous cord blood plasma.

$\mathrm{CD}^{+}$(helper T cell)

$\mathrm{CD} 8^{+}$(cytotoxic T cell)

$\mathrm{CD} 25^{+}$(activated $\mathrm{T}$ cell)

$\mathrm{CD}^{2} 8^{+}$(immature T cell)

$\mathrm{CD}_{45 \mathrm{RA}^{+}}$(naive T cell)

$\mathrm{CD}^{2} 5 \mathrm{RO}^{+}$(memory T cell) 
$\mathrm{CD}^{+} \mathrm{CD} 25^{+}$(activated T cell, $9.95 \% \pm 3.01 \%$ vs $96.17 \% \pm 3.14 \%$ ), $\mathrm{CD}^{+} \mathrm{CD} 38^{+}$(immature $\mathrm{T}$ cell, $62.61 \% \pm 8.37 \%$ vs $96.86 \% \pm 3.08 \%$ ), and $\mathrm{CD}^{+} \mathrm{CD} 45 \mathrm{RO}^{+}$(memory $\mathrm{T}$ cell, $4.38 \% \pm 3.70 \%$ vs $58.92 \% \pm 15.05 \%$ ) was significantly increased, whereas the expression of $\mathrm{CD}^{+} \mathrm{CD}^{2} 5 \mathrm{RA}^{+}$(naive $\mathrm{T}$ cell, $66.23 \% \pm 5.56 \%$ vs $29.13 \% \pm 24.72 \%$ ) and $\mathrm{CD}_{16}{ }^{+} \mathrm{CD}^{+} 6^{+}$(NK cell, $9.22 \% \pm 9.16 \%$ vs $0.63 \% \pm 0.40 \%)$ was significantly decreased $(p<$ 0.05 each), compared with pre-cultured cells (Fig. $3)$. The $\mathrm{CD}^{+} / \mathrm{CD}^{+}$ratio was decreased, but remained over 1 on day 8 , indicating that, in medi- um supplemented with FBS, $\mathrm{CD}^{+}$cells have greater proliferation potential than $\mathrm{CD} 8^{+}$cells. When cultured in medium supplemented with $\mathrm{HCBP}$, the proportion of $\mathrm{CD}^{+} \mathrm{CD}^{+}(19.78 \% \pm$ $7.66 \%$ vs $81.13 \% \pm 7.66 \%), \mathrm{CD}^{+} \mathrm{CD} 25^{+}(9.95 \%$ $\pm 3.01 \%$ vs $74.54 \% \pm 19.8 \%), \mathrm{CD}^{+} \mathrm{CD} 45 \mathrm{RA}^{+}$ $(66.23 \% \pm 5.56 \%$ vs $87.68 \% \pm 5.56 \%)$, and $\mathrm{CD}^{+}{ }^{+} \mathrm{CD} 45 \mathrm{RO}^{+}(4.38 \% \pm 3.70 \%$ vs $29.39 \% \pm$ $3.70 \%)$ cells was significantly increased $(p<0.05$ each), while the proportion of $\mathrm{CD}^{+} \mathrm{CD} 4^{+}$ $(49.58 \% \pm 11.80 \%$ vs $31.32 \% \pm 11.80 \%)$ and $\mathrm{CD}^{+}{ }^{+} \mathrm{CD} 38^{+}(74.67 \% \pm 6.24 \%$ vs $80.60 \% \pm$



Fig. 3. Analysis of cell surface phenotype before and after culture for 8 days in medium supplemented with $10 \%$ FBS. The percentages of $\mathrm{CD}^{+} \mathrm{CD}^{+}, \mathrm{CD}^{+} \mathrm{CD} 8^{+}, \mathrm{CD}^{+} \mathrm{CD} 25^{+}, \mathrm{CD} 3^{+} \mathrm{CD} 38^{+}$, and $\mathrm{CD}^{+} \mathrm{CD} 45 \mathrm{RO}^{+}$cells were significantly increased, whereas the percentages of $\mathrm{CD}^{+} \mathrm{CD}^{+} 5 \mathrm{RA}^{+}$and $\mathrm{CD}_{16} 6^{+} \mathrm{CD} 56^{+}$(NK cells) were significantly decreased $(p<0.05$ each), compared with pre-cultured cells. FBS, fetal bovine serum.

$\square$, before culture-mean \pm S.D.; $\square$, FBS-mean \pm S.D.

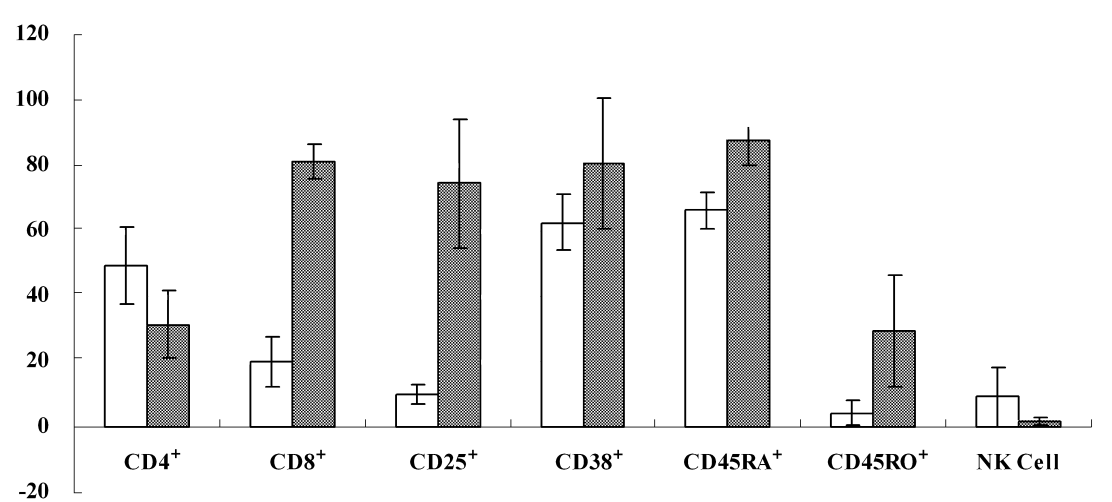

Fig. 4. Analysis of cell surface phenotype before and after culture for 8 days in medium supplemented with $10 \%$ HCBP. The percentages of $\mathrm{CD}^{+} \mathrm{CD}^{+}, \mathrm{CD}^{+} \mathrm{CD} 25^{+}, \mathrm{CD}^{+} \mathrm{CD} 45 \mathrm{RA}^{+}$, and $\mathrm{CD}^{+} \mathrm{CD}^{2} 5 \mathrm{RO}^{+}$were significantly increased $\left(p<0.05\right.$ each), while the percentages of $\mathrm{CD}^{+} \mathrm{CD}^{+}$ and $\mathrm{CD}^{+} \mathrm{CD}^{+} 8^{+}$cells were also changed, but not significantly $(p>0.05$ each), compared with precultured cells. HCBP, homologous cord blood plasma.

$\square$, before culture-mean \pm S.D.; $\square$, HCBP-mean \pm S.D. 


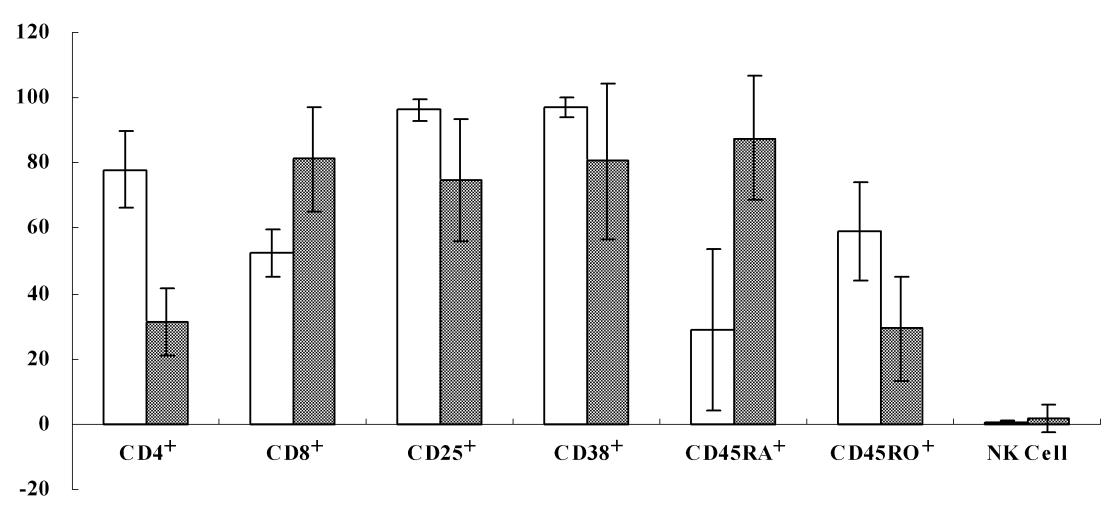

Fig. 5. Comparison of cell surface phenotype after culture for 8 days in media supplemented with FBS and HCBP. Compared with cells grown in FBS-supplemented medium, the percentages of $\mathrm{CD}^{+}{ }^{+} \mathrm{CD} 45 \mathrm{RA}^{+}$and $\mathrm{CD}^{+} \mathrm{CD}^{+}$cells were significantly higher, while the percentages of $\mathrm{CD} 3^{+} \mathrm{CD} 4^{+}$, $\mathrm{CD}^{+}{ }^{+} \mathrm{CD} 45 \mathrm{RO}^{+}$and $\mathrm{CD}^{+} \mathrm{CD} 38^{+}$cells were significantly lower $(p<0.05$ each), in HCBP-supplemented medium. FBS, fetal bovine serum; HCBP, homologous cord blood plasma.

$\square$, FBS-mean \pm S.D.; $\square$, HCBP-mean \pm S.D.

$7.01 \%)$ cells was also changed, but not significantly ( $p>0.05$ each) (Fig. 4 ). The $\mathrm{CD}^{+} / \mathrm{CD}^{+}$ ratio was reversed, indicating that in medium supplemented with $\mathrm{HCBP}, \mathrm{CD} 8^{+}$cells have a greater proliferation potential than CD4 cells. Compared with cells grown in FBS-supplemented medium, the expression of $\mathrm{CD}^{+}{ }^{+} \mathrm{CD} 45 \mathrm{RA}^{+}$and $\mathrm{CD}^{+} \mathrm{CD}^{+}$ was significantly higher, while the expression of $\mathrm{CD}^{+} \mathrm{CD}^{+}, \mathrm{CD}^{+} \mathrm{CD}^{+} 5 \mathrm{RO}^{+}$and $\mathrm{CD}^{+} \mathrm{CD} 38^{+}$was significantly lower ( $p<0.05$ each), in HCBPsupplemented medium (Fig. 5).

\section{Discussion}

In all cellular immunotherapies, immune cells must be isolated from the patient or an allogeneic donor and expanded ex vivo before re-infusion into the patient. The efficacy of these therapies is highly dependent on the number of cells infused and increases with the dose (Cheever et al. 1997). Typically, between $10^{9}$ and $10^{11}$ cells are required for cellular immunotherapy protocols. Furthermore, the infused cells must be biologically active. They must be able to home to the necessary sites, interact with other immune cells and perform their respective functions, such as release of cytokines or cytolytic attack on aberrant cells. Since the survival and performance of T cells in vivo is highly dependent on ex vivo culture conditions (Cheever and Chen 1997), optimi- zation of culture parameters to maximize proliferation and function is critical for successful immunotherapies.

We have investigated the use of HCBP as a culture supplement during the ex vivo expansion of UCB T lymphocytes in the presence of IL-2 and anti-CD3 antibody. IL-2 is an important growth factor for $\mathrm{T}$ lymphocytes, and its receptor, IL-2R, is a $T$ cell surface protein critical for the proliferation of these cells. When $\mathrm{T}$ cells are activated by anti-CD3 monoclonal antibodies, they undergo a dramatic upregulation of IL-2R, which peaks after 2 to 8 days, depending on the stimulant (Biselli et al. 1992; Caruso et al. 1997).

In assessing the proliferation of lymphocyte populations from human UCB in medium supplemented with HCBP, we focused on cell phenotype. Our results showed that overall cell proliferation in HCBP-supplemented medium was similar to that in FBS-supplemented medium, and was thus sufficient for adoptive cellular immunotherapy. Although more than $95 \%$ of expanded cells in both culture systems were positive for CD3, their phenotypes differed somewhat. Expansion in HCBP supplemented medium significantly increased the levels of cytotoxic $\mathrm{T}$ cells $\left(\mathrm{CD} 3{ }^{+} \mathrm{CD} 8^{+}\right.$cells) and immature $\mathrm{T}$ cells $\left(\mathrm{CD}^{+}{ }^{+} \mathrm{CD} 45 \mathrm{RA}^{+}\right.$cells), whereas expansion in FBS supplemented medium significantly increased the 
level of primitive $\mathrm{T}$ cells $\left(\mathrm{CD}^{+} \mathrm{CD} 38^{+}\right.$cells $)$. In the latter medium, expansion of UCB T cells is accompanied by both $\mathrm{T}$ cell activation and maturation, as evidenced by the significantly enhanced proportion of $\mathrm{CD}^{+} \mathrm{CD} 38^{+}$cells and the change in proportion of $\mathrm{CD}^{+} \mathrm{CD} 45^{+}$cells from the immature $\mathrm{CD}^{+} \mathrm{CD} 45 \mathrm{RA}^{+}$isoform to the more mature $\mathrm{CD}^{+} \mathrm{CD} 45 \mathrm{RO}^{+}$isoform. In HCBP supplemented medium, cells exhibit a phenotypic change over time in terms of the type of $\mathrm{T}$ cell that predominates. Although the $\mathrm{CD} 4^{+} / \mathrm{CD}^{+}$ratio in both media decreased gradually during culture, the time at which this ratio became reversed appeared to be delayed in HCBP supplemented cultures (data not shown). That is, $\mathrm{CD}^{+} \mathrm{T}$ lymphocytes predominate early, whereas $\mathrm{CD}^{+} \mathrm{T}$ lymphocytes predominate later (Skea et al. 2002). The ability of both FBS and HCBP to expand purified populations of $\mathrm{CD}^{+}$and $\mathrm{CD}^{+}$cells and the kinetics of growth suggest that this apparent switchover is not due to cross-regulation of $\mathrm{CD}^{+}$and $\mathrm{CD} 8^{+}$cell subsets but rather to different growth rates and life spans. The delay in the reversal of the $\mathrm{CD} 4^{+} / \mathrm{CD} 8^{+}$ratio in HCBP supplemented cultures may therefore be a result of less vigorous proliferation of $\mathrm{CD}^{+} \mathrm{T}$ cells.

The results of our study clearly show the feasibility of human UCB T lymphocyte expansion in HCBP supplemented medium, thus suggesting that HCBP can be used clinically as an alternative to FBS for ex vivo T lymphocyte expansion. Moreover, the characteristic growth pattern caused by HCBP may be used to selectively expand different functional $\mathrm{T}$ cell subsets, which could be useful in producing desired populations of T lymphocytes suitable for adoptive $\mathrm{T}$ cell immunotherapy applications. For example, $\mathrm{CD}^{+}$ cytolytic T lymphocytes could be used to eradicate residual tumor cells in cancer patients or residual virally infected cells in patients with AIDS or other infectious diseases. $\mathrm{CD} 4^{+}$cells could provide essential helper functions for these cytolytic cells in vivo or could be exploited for their own endogenous antitumor or antiviral activities or even for regulatory activities that may be of benefit in transplantation and in the treatment of autoimmune diseases. Studies are currently un- derway to expand populations of antigen-specific $\mathrm{T}$ lymphocytes to therapeutically useful doses. However, the clinical benefits and long-term consequences remain to be determined.

\section{References}

Azuma, H., Yamada, Y., Shibuya-Fujiwara, N., Yamaguchi, M., Murahashi, H., Fujihara, M., Sato, N., Fukazawa, K., Ikebuchi, K. \& Ikeda, H. (2002) Functional evaluation of ex vivo expanded cord blood lymphocytes: possible use for adoptive cellular immunotherapy. Exp. Hematol., 30, 346-351.

Barker, J.N., Martin, P.L., Coad, J.E., DeFor, T., Trigg, M.E., Kurtzberg, J., Weisdorf, D.J. \& Wagner, J. (2001) Low incidence of Epstein-Barr virusassociated posttransplantation lymphoproliferative disorders in 272 unrelated-donor umbilical cord blood transplant recipients. Biol. Blood Marrow Transplant., 7, 395-399.

Bertotto, A., Gerli, R., Lanfrancone, L., Crupi, S., Arcangeli, C., Cernetti, C., Spinozzi, F. \& Rambotti, P. (1990) Activation of cord T lymphocytes. II. Cellular and molecular analysis of the defective response induced by anti-CD3 monoclonal antibody. Cell Immunol., 127, 247-259.

Biselli, R., Matricardi, P.M., D’Amelio, R. \& Fattorossi, A. (1992) Multiparametric flow cytometric analysis of the kinetics of surface molecule expression after polyclonal activation of human peripheral blood T lymphocytes. Scand. J. Immunol., 35, 439-447.

Carlens, S., Gilljam, M., Remberger, M., Aschan, J., Christensson, B. \& Dilber, M.S. (2000) Ex vivo $\mathrm{T}$ lymphocyte expansion for retroviral transduction: influence of serum-free media on variations in cell expansion rates and lymphocyte subset distribution. Exp. Hematol., 28, 1137-1146.

Caruso, A., Licenziati, S., Corulli, M., Canaris, A.D., De, F.M.A., Fiorentini, S., Peroni, L., Fallacara, F., Dima, F., Balsari, A. \& Turano, A. (1997) Flow cytometric analysis of activation markers on stimulated $\mathrm{T}$ cells and their correlation with cell proliferation. Cytometry, 27, 71-76.

Chang, A.E., Aruga, A., Cameron, M.J., Sondak, V.K., Normolle, D.P., Fox, B.A. \& Shu, S. (1997) Adoptive immunotherapy with vaccine-primed lymph node cells secondarily activated with anti-CD3 and interleukin-2. J. Clin. Oncol., 15, 796-807.

Cheever, M.A. \& Chen, W. (1997) Therapy with cultured T cells: principles revisited. Immunol. 
Rev., 157, 177-194.

Conrad, P.D. \& Emerson, S.G. (1998) Ex vivo expansion of hematopoietic cells from umbilical cord blood for clinical transplantation. J. Leukoc. Biol., 64, 147-155.

Curti, B.D., Ochoa, A.C., Powers, G.C., Kopp, W.C., Alvord, W.G., Janik, J.E., Gause, B.L., Dunn, B., Kopreski, M.S., Fenton, R., Zea, A., Dansky-Ullmann, C., Strobl, S., Harvey, L., Nelson, E., Sznol, M. \& Longo, D.L. (1998) Phase I trial of anti-CD3-stimulated CD4 ${ }^{+} \mathrm{T}$ cells, infusional interleukin-2, and cyclophosphamide in patients with advanced cancer. $J$. Clin. Oncol., 16, 2752-2760.

D’Arena, G., Musto, P., Cascavilla, N., Di Giorgio, G., Zendoli, F. \& Carotenuto, M. (1996) Human umbilical cord blood: immunophenotypic heterogeneity of $\mathrm{CD} 34^{+}$hematopoietic progenitor cells. Haematologica, 81, 404-409.

Gluckman, E., Rocha, V., Boyer-Chammard, A., Locatelli, F., Arcese, W., Pasquini, R., Ortega, J., Souillet, G., Ferreira, E., Laporte, J.P., Fernandez, M. \& Chastang, C. (1997) Outcome of cord-blood transplantation from related and unrelated donors. Eurocord Transplant Group and the European Blood and Marrow Transplantation Group. N. Engl. J. Med., 337, 373-381.

Harris, D.T., Schumacher, M.J., Locascio, J., Besencon, F.J., Olson, G.B., DeLuca, D., Shenker, L., Bard, J. \& Boyse, E.A. (1992) Phenotypic and functional immaturity of human umbilical cord blood T lymphocytes. Proc. Natl. Acad. Sci. USA, 89, 10006-10010.

Lewis, I.D. (2002) Clinical and experimental uses of umbilical cord blood. Intern. Med. J., 32,
601-609.

Mehta-Damani, A., Markowicz, S. \& Engleman, E.G. (1994) Generation of antigen-specific CD8 ${ }^{+}$ CTLs from naive precursors. J. Immunol., 153, 996-1003.

Risdon, G., Gaddy, J., Horie, M. \& Broxmeyer, H.E. (1995) Alloantigen priming induces a state of unresponsiveness in human umbilical cord blood T cells. Proc. Natl. Acad. Sci. USA, 92 , 2413-2417.

Rooney, C.M., Smith, C.A., Ng, C.Y., Loftin, S.K., Sixbey, J.W., Gan, Y., Srivastava, D.K., Bowman, L.C., Krance, R.A., Brenner, M.K. \& Heslop, H.E. (1998) Infusion of cytotoxic T cells for the prevention and treatment of Epstein-Barr virus-induced lymphoma in allogeneic transplant recipients. Blood, $\mathbf{9 2}$, 1549-1555.

Skea, D., Chang, N.H., Hedge, R., Dabek, B., Wong, T., Wettlaufer, B. \& Bell, D. (1999) Large ex vivo expansion of human umbilical cord blood $\mathrm{CD} 4^{+}$ and $\mathrm{CD}^{+}$T cells. J. Hematother., 8, 129-139.

Wagner, J.E., Rosenthal, J., Sweetman, R., Shu, X.O., Davies, S.M., Ramsay, N.K., McGlave, P.B., Sender, L. \& Cairo, M.S. (1996) Successful transplantation of HLA-matched and HLA-mismatched umbilical cord blood from unrelated donors: analysis of engraftment and acute graftversus-host disease. Blood, $\mathbf{8 8}, 795-802$.

Walter, E.A., Greenberg, P.D., Gilbert, M.J., Finch, R.J., Watanabe, K.S., Thomas, E.D. \& Riddell, S.R. (1995) Reconstitution of cellular immunity against cytomegalovirus in recipients of allogeneic bone marrow by transfer of T-cell clones from the donor. N. Engl. J. Med., 333, 1038-1044. 